\title{
Methodology to Study Behavioral Aggression Due to the Impact of Television Programs
}

\author{
Yurii Havrylets a *, Volodymyr Rizun a, Sergii Tukaiev b, Mykola Makarchuk b \\ a Institute of Journalism, Taras Shevchenko National University of Kyiv, 36/1 Melnikova str., \\ Kyiv, 04119, Ukraine \\ b Institute of Biology, Taras Shevchenko National University of Kyiv, 2 Akademika Hlushkova \\ avenue, Kyiv, 04119, Ukraine \\ * Corresponding author's e-mail address: youri1985@gmail.com
}

\begin{abstract}
The problem of violence on television and its impact on behavioural aggression of the audience occupies a leading position in media effects studies. The main objective of the study was to explore the available methodology used by scientists in the United States and in the European Union to explore the behavioural aggression due to the impact of television programs.

Through the classification of findings of the television-induced aggression empirical studies, the methodological framework of the main research methods in this field was formulated. This structure contains two basic types of research methods. First one studies the media-induced aggressive behaviour (using observation and fixing of aggression acts); second one explores the media impact on viewers' aggressive inclinations. The latter type of techniques does not deal with the behaviour, but only with the ability to act aggressively, and with its help the researcher can only make inference about the likelihood of aggressive actions in the future. Thus, an empirical study of aggressive behaviour is in many aspects more complicated, but this approach allows obtaining more statistically significant data. Instead of that, evaluating aggressive inclinations enables accumulating a large amount of raw (unprocessed) data in faster and easier way.

Results / findings. The first attempt was made to systemize all the methods of the TV-induced aggression studies, used by the U.S. and the EU scientists in their respective explorations. Special emphasis was made on the usage of the psycho-physiological measurements in the experimental research of the TV violence impact. It was found that due to the lack of sufficient veracity in the estimation of the impact of long-term media effects, the methods of fixing the short-term effects prevail in the majority of respective studies. Our further studies in this respect will be concentrated on the problematic of formation of aggressive tendencies under the influence of television programs in the long run.
\end{abstract}

KEYWORDS: aggressiveness, experiment, meta-analysis, TV-violence, media effect. 


\section{Методики вивчення агресивності глядачів під впливом телевізійних програм}

Гаврилець Юрій Дмитрович, Інститут журналістики Київського національного університету імені Тараса Шевченка, молодший науковий співробітник, кандидат наук із соцііальних комунікацій

Різун Володимир Володимирович, Інститут журналістики Київського національного університету імені Тараса Шевченка, професор, доктор філологічних наук

Тукаєв Сергій Вікторович, ННЦ «Інститут біології» Київського національного університету імені Тараса Шевченка, старший науковий співробітник, кандидат біологічних наук

Макарчук Микола Юхимович, ННЦ «Інститут біології» Київського національного університету імені Тараса Шевченка, професор, доктор біологічних наук

\section{Резюме}

Метою пропонованого дослідження було систематизувати методики, які використовують науковці у США та Європейському Союзі для вивчення агресії глядачів під впливом телевізійного насильства. За допомогою класифікації емпіричних праць було сформульовано типологію методик вивчення агресивності глядачів під впливом телевізійних програм. 3'ясовано, що два основні види методик, які насамперед використовують американські вчені - це дослідження медіавпливів на агресивну поведінку, а також вивчення впливів медіа на схильність до агресії. При цьому, слід відзначити як складніший із багатьох поглядів для практичного застосування перший підхід, однак він дає змогу отримувати інформативніші дані. У дослідженні акцент зроблено на методиках вимірювання психофізіологічних реакцій як ефекту впливу телевізійного насильства.

Ключові слова: агресивність, експеримент, теленасильство, медіаефект.

Гаврилец Ю.Д., Ризун В.В., Тукаев С.В., Макарчук Н.Ю. Методики изучения агрессивности зрителей под влиянием телевизионных программ.

Резюме. Целью предлагаемого исследования было систематизировать методики, которые используют ученые в США и Евросоюзе для изучения агрессии зрителей под влиянием телевизионного насилия. Методом классификации методик эмпирических работ было сформулировано типологию методик изучения агрессивности зрителей под влиянием телевизионных программ. Поэтому основные два вида методик, которые используются в первую очередь американскими учеными - это исследование влияний СМИ на агрессивное поведение, а также изучение воздействия масс-медиа на склонность к агрессии. При этом, следует отметить как более сложный для практического применения первый подход, однако он позволяет получать более информативные данные. В исследовании акцентируется внимание на методиках измерения психофизиологических реакций как эффекта воздействия телевизионного насилия.

Ключевые слова: агрессивность, эксперимент, теленасилие, медиаэффект. 


\section{1. Вступ}

Соціальні комунікації як галузь знань дедалі сильніше інтегруються не лише з суспільними, а й із природничими науками, успішно використовуючи у своїх дослідженнях методи біології, фізики та споріднених із ними ділянок науки. Такі дослідження набагато складніше проводити, проте цінність їх результатів - набагато вища. Міждисциплінарний контекст досліджень мас-медіа, особливо їхнього впливу на свого глядача / слухача / читача (з залученням методик точних наук для вимірювання зворотного зв'язку від вибірок) вже віддавна домінує в працях науковців Свросоюзу та США.

Не применшуючи ролі досліджень мас-медійного контенту, слід наголосити, що навіть усебічне вивчення, скажімо, кількох випусків певної телепрограми не дає науковцеві можливості хоча б приблизно простежити зв'язок між медіаповідомленням та його впливом на свідомість та поведінку представників аудиторії. Дослідник може лише робити припущення про можливі ефекти впливу. Однак, роблячи припущення, слід і перевіряти результат. Тому саме експериментальні праці, умови яких, по-перше, контролюються дослідником, по-друге, показують зміни психофізіологічного стану чи поведінки вибірки досліджуваних осіб під упливом медіа, по-третє, дають можливість ще й формулювати гіпотези, аналізувати числовий вираз впливу через коефіцієнти кореляції і статистичну значущість результатів перевірки гіпотези. А тому, крім психології, психофізіології, у таких працях стає актуальною ще й статистика.

Для дослідників медіаефектів важливо знати, як контент впливає на реципієнтів. Проте якими можуть бути ці впливи? Загальноприйнятим є їх поділ дослідниками [1; 2] на просоціальні та антисоціальні. Тож вплив медіа на людину як істоту соціальну може бути до певної міри причиною ii поведінки у своєму оточенні. Чим зумовлений цей вплив та його ефекти, або прояви? Чи лише негативні наслідки може спричиняти рецепція контенту мас-медіа? Якщо перегляд насильства по телебаченню може викликати погіршення настрою та тривоги [3], то чи може людина під упливом таких станів психіки зважитися діяти агресивно щодо інших людей навколо? Які типи медіапродуктів найбільше сприяють виникненню агресії? I що найважливіше - як людина може долати деструктивні переживання? Ці та багато інших питань постають перед ученими у всьому світі, проте на більшість із них однозначних відповідей наразі нема.

На нинішньому етапі міждисциплінарних досліджень, коли представники різних наукових дисциплін працюють для отримання спільних результатів, важливим аспектом $€$ дослідження медіавпливу та його ефектів (проявів) на поведінці, емоційному стані та стані здоров'я - фізичного та психічного - представників аудиторії. Цікавим для дослідників є вивчення медіанасильства та його впливу на здійснення агресивних дій споживачами продуктів ЗМК з умістом насильства. Тому першим кроком для українських дослідників у розробці цієї проблеми для різних видів медіаконтенту постає вивчення методик, які широко застосовуються не один десяток років колеги зі США та Західної Європи. А для цього слід ознайомитися з інструментарієм використовуваних у працях європейських та американських науковців методик, щоб можна було їх застосовувати в умовах, доступних для українських науковців. Наукова новизна полягає в можливості порівняння наявних експериментальних методик та можливості їхньої реалізації українськими дослідниками. Стійкої класифікації методик за типами ефектів раніше зроблено не було.

Метою цієї статті є показати, які методики використовуються американськими та європейськими вченими для вивчення процесу появи агресії під упливом телевізійних програм, зокрема теленовин. А також яким чином ці методики знаходять своє застосування.

Для досягнення цієї мети були поставлені такі завдання:

1) сформулювати типологію методик вивчення агресії під упливом перегляду телевізійного контенту за видами медіаефектів; 
2) навести переваги й вади різних методик фіксації та інтерпретації медіаефектів агресивності;

3) означити місце методик фіксації психофізіологічних реакцій досліджуваних на тлі решти методів вивчення агресивності.

Тож предметом дослідження є методики фіксації та інтерпретації короткотривалих психоемоційних та психофізіологічних реакцій агресивності на перегляд новинного телевізійного контенту.

За останне десятиліття з'явилося чимало праць, присвячених дослідженню різного роду впливів телевізійного контенту $[3 ; 4 ; 5 ; 1 ; 2]$. Тому цікаво було визначити, які методики використовують учені зі США та Західної Європи для оцінки або вимірювання, обробки та інтерпретації даних щодо різнопланових впливів телевізійного контенту на агресивність представників аудиторії. Щоправда, до уваги бралися дослідження впливу телевізійного насильства на подальшу агресивність глядачів.

\section{2. Методи дослідження}

Загалом вивчення медіаефектів так чи інакше пов'язане з використанням методів експерименту та спостереження, а також, коли йдеться про пізнання довготривалих медіаефектів, то звітів, анкетування та різноманітних тестів.

У цій статті основними методами, які було використано для вивчення методик досліджень медіаефектів, $є$ такі: теоретичний аналіз наукової літератури, типологічний аналіз на основі класифікації наявних методик експериментального вивчення медіаефектів, метод аналізу документів, зокрема аналіз результатів експериментальних досліджень.

Стрижнем нашого дослідження типологічний аналіз, зроблений на основі класифікації. Остання була сформована за підсумками аналізу теоретичного аналізу літератури. Типологія завжди створюється за допомогою класифікації, свого основного інструмента, який дозволяє провести паралелі між певними явищами і процесами дійсності і за результатами такого аналізу створити певну структуру досліджуваних об'єктів. Класифікація покликана встановити зв'язки і закономірності розвитку тих чи інших фрагментів довколишньої реальності. Часто класифікація має місце завдяки групуванню, яке «дає змогу поділити цілісну сукупність об'єктів чи даних на однорідні групи так, щоб розходження всередині групи були менші, ніж між групами. Проводячи групування. важливо забезпечити однорідність і порівнюваність ознак, за якими здійснюється розподіл» [6, 19-20].

Класифікація за певними ознаками і критеріями дає змогу виявити деякі загальні закономірності в різних явищах дійсності, окреслити можливі причинно-наслідкові зв'язки між різнорідними фактами та тенденціями. Щоправда, щоб довести наявність таких зв'язків, даних самої лише класифікації не досить, тут слід застосовувати інші методи дослідження. Але саме класифікація дає змогу побачити чи «запідозрити» наявність причиннонаслідкових залежностей.

Результатом класифікації повинна бути типологія - «метод (а також результат) наукового пізнання, наукової систематизаџії, класифікаиії (зокрема газет, журналів, телерадіопрограм) на основі загальних для них ознак $і$ властивостей» $[6,20]$. Метод типологізації має на меті пошук стійких ознак і властивостей досліджуваних об'єктів. Наприклад, тип видання - це певний узагальнений образ, що повторюється в тій чи іншій мірі в групі реально існуючих засобів масової інформації. «Центральне поняття типологічного методу - тип як модель, щэо відбиває деякі істотні ознаки певної кількості явищ, але свідомо ігнорує інші ознаки, які в иьому випадку вважаються несуттєвими» $[6,20]$. Типологія має справу з певним еталонним зразком, яким у нашій статті $є$ методика вивчення агресивності під упливом мас-медіа. 
Спочатку трохи визначень. Медіанасильство - це контент ЗМК, який містить значний ступінь сцен насильства та агресії. На думку Л. Х’юзмена, - це «візуальне зображення актів фізичної агресії, заподіяних однією людиною або людиноподібним персонажем іншій (іншому)» [7].

Поведінкова агресія - це «будь-яка поведінка, спрямована щзодо іншого індивіда, яка здійснюється з негайним наміром завдати шкоди. Також ініціатор агресії (нападник) має вірити, щзо ия поведінка заподіє шкоду «мішені», а також щзо жертва агресї має мотиваиію на уникнення від спрямованих проти себе агресивних дій» [2, 114: 8].

Медіаефект - це результат впливу мас-медіа на реципієнта. При цьому ефектом може бути будь-що: як поганий настрій зранку після нічного перегляду блокбастера, так і рішення купити певний товар після випадкового перегляду реклами. В цьому контексті поділ Р. Харрісом [9] медіаефектів на поведінкові, настановчі, когнітивні та фізіологічні вважаємо логічним, адже поданий поділ відображає різні сфери життєдіяльності людини, на які впливають мас-медіа своїм контентом. Також медіаефекти поділяють на короткротривалі та довготривалі. «Під короткотривалими медіаефектами слід розуміти такі реакиії людського організму на медіаповідомлення, які не усвідомлюються мовцем, є прихованими і тимчасовими, але які від частого повторення можуть «запускати» довготривалі реакиії в людському організмі, щчо усвідомлюються» [3, 74]. Довготривалі ефекти можна вважати розтягнутими в часі накопиченнями короткотривалих.

\section{3. Результати й обговорення}

Основним інтересом у цій статті $є$ агресивність у контексті короткотривалих ефектів впливу мас-медіа. Адже коли аналізуються певні дії індивіда, відірвані в часі від споживання (перегляду) певних телепрограм або відеороликів, то залежна змінна в таких дослідах стає надто розмитою, що робить доцільність проведення експерименту та валідність майбутніх результатів практично нульовими. На наше переконання, без досконалого i вичерпного пізнання короткотривалих ефектів медіанасильства не можна братися за лонгітюдні дослідження агресивності, спровокованої мас-медіа.

Р. Харріс окреслив наступні чотири види медіаефектів: поведінкові, когнітивні, настановчі та фізіологічні [9, 23-26]. Виходячи з цього поділу, вивчення агресивності під упливом мас-медіа може відбуватися також у чотирьох контекстах: 1) поведінкова агресія; 2) оцінка різноступеневих агресивних афектів або схильностей до агресії (без вивчення актів поведінки); 3) вплив медіанасильства на когнітивні можливості індивіда (здатність сприймати та обробляти інформацію); 4) вивчення інших психофізіологічних чинників (погіршення настрою, тривожності, емоційних станів тощо) [2, 114]. Перші два види методик можна вважати базовими у дослідженнях агресивності, другі - супровідними, які дають краще розуміння аналізованого явища, проте самі по собі не характеризують агресивність досліджуваних. Тому «когнітивні» та «психофізіологічні» методики рідко використовуються поодиноко для вивчення ефектів впливу медіанасильства, а лише поряд із дослідженнями на основі аналізу агресивної поведінки чи схильностей до агресії, адже фіксують психоемоційний стан людини в даний момент часу та, відповідно, іiі здатність засвоювати нову інформацію. Розгляньмо детальніше зазначені види методик у контексті практичних аспектів їхнього застосування, а також їхніх переваг та вад.

1. Дослідження поведінкової агресії. Основним масивом наукових праць із застосуванням експериментального вивчення поведінкової агресії є експерименти соціальних психологів А. Басса [10] та С. Мілграма [11] та їхні подальші прототипи. Хоча зазначені праці мали на меті вивчення меж людської слухняності і до медіаефектів не мали стосунку, проте модифікації цього експерименту дали можливість застосовувати таку методику і в нашій сфері. Процедура дослідів зводиться до такого. Є дві групи досліджуваних. Кожного 3 
першої групи запрошують і показують певний відеоролик (або кілька) з умістом насильства. Досліджуваним іншої групи показують нейтральний за емоційним фоном відеоматеріал, наприклад новинний огляд світових ринків). Після перегляду кожному досліджуваному 3 обох груп дають змогу проявити агресію щодо асистента експериментатора, який у деяких випадках під час перегляду провокує досліджуваних на різку реакцію: ображає, насміхається. Агресію досліджуваний може проявити, натиснувши фіктивну кнопку електричного розряду ${ }^{1}$. Покарання в різних працях різняться між собою. Іноді досліджувані можуть регулювати кількість завданих ударів електрики, в інших випадках також і силу «струму». Відмінності в реакціях представників обох груп і являють різний ефект поведінкової агресії під упливом переглянутих медіапродуктів. Одним із таких експериментів була праця Е. Доннерстайна та Л. Берковіца [12], в якій був досліджений вплив насильства в еротичних фільмах на подальші агресивні дії досліджуваних чоловіків щодо жінок, так само за допомогою «електричної кнопки». Зауважимо, що такі експерименти мають суттєве застереження щодо етичності їх проведення. Хоча дані свідчать про певну агресивну поведінку як ефект певних стимулів, проте досліджуваного в процесі експерименту, по суті, дурять і він не усвідомлює постановочного характеру досліду. I тільки після завершення процесу йому проливають світло на суть досліду. Чи виправдано це? Так, з огляду на високу валідність майбутніх результатів. Також важливо і те, що останні вдається отримати, не вивчаючи, скажімо, побиття одних людей іншими, спровоковане експериментатором (такі досліди не були б гуманними), а мінімізація заподіяння шкоди життю і здоров'ю людей, - вже позитивна сторона таких досліджень.

Також у контексті досліджень агресії в поведінці людей під упливом перегляду телевізійного контенту варто торкнутися питання вибору польової чи лабораторної моделі експерименту. Якщо лабораторні експерименти агресивної поведінки зводяться до модифікацій дослідів А. Басса та С. Мілграма, то методики польових досліджень такої поведінки мають більш розгалужену структуру:

1) самозвіти досліджуваних. Це як звіти про власну агресивну поведінку за певний період часу, так і різноманітні психологічні тести щодо рівня агресивності. Такі методики варіюються від одноразових до періодичних. Звіти про зміни у власній поведінці використовуються рідше, бо досліджуваний іноді може бути необ'єктивним у таких оцінках. Краще використовувати апробовані на численних вибірках психодіагностичні опитувальники. Як от, приміром, шкала агресивності А. Басса - М. Перрі [13], опитувальник щодо агресивності [14] та шкала оцінок фізичного насильства [15].

2) звіти інших осіб. Це письмові звіти, написані ровесниками, вчителями, батьками досліджуваного про зміни в його поведінці за останній час. Дещо об'єктивніші, такі звіти також пишуться (заповнюються) 3 певною періодичністю в лонгітюдних польових дослідженнях.

3) пряме відеоспостереження. Цей метод використовується зазвичай для досліджень агресивності дітей [16]. Після перегляду досліджувані йдуть у певне приміщення (спортивний майданчик школи), де перебувають протягом певного періоду часу разом. При цьому вони не знають про приховане відеоспостереження і поводять себе невимушено. При цьому експериментатор не дає ніяких інструкцій щодо поведінки. Вони можуть робити все, що їм забажається. Однак певні труднощі постають, коли потрібно інтерпретувати ту чи іншу дію досліджуваного як агресивну чи неагресивну. Як загалом у соціальних науках, у цьому випадку слід операціоналізувати акти агресивної поведінки і зробити це при підготовці експерименту. Закордонні вчені розв’язують цю проблему через формулювання кодів-дій окремо для агресивної та неагресивної поведінки щодо своїх ровесників чи колег

\footnotetext{
${ }^{1}$ Для досліджуваного покарання реальне, бо асистент кричить від «болю» і просить зупинитися, все свідчить про реальність того, що відбувається.
} 
[2, 116]. Якщо сума агресивних дій вища в тієї частини вибірки, що дивилася одну добірку телевізійного контенту, ніж у контрольної групи, це може свідчити про поведікову агресію під впливом контенту медіа.

Базовою відмінністю польового та лабораторного експериментів - у тому, що в першому випадку створюються умови, більш звичні та комфортні для досліджуваного. Позаяк лабораторний експеримент прив'язаний до певного місця ${ }^{2}$, яке може викликати у досліджуваного негативні асоціації, польовий експеримент позбавлений цих вад.

Натомість значною перевагою експерименту в лабораторії $є$ повна доступність усіх даних після закінчення досліду. Проте це не стосується польових експериментів, в яких, на жаль, ніколи всі досліджувані не віддають заповнені звіти чи анкети. Тому основним завданням експериментатора в лабораторному експерименті є заспокоїти досліджуваного, сказати йому, що жодної шкоди для здоров'я дослід не несе і попросити поводити себе так, як він звик це робити вдома, дивлячись телевізор.

2. Оиінка ступеня психоемоційної агресивності (без аналізу поведінки). Якщо перший вид методик зосереджується на агресивній поведінці як ефекті засобів масової комунікації, то тут до уваги береться ступінь відчуття агресії під упливом медіаконтенту. На цьому тлі робиться лише припущення щодо можливої агресивної поведінки у майбутньому, виходячи з відчуттів досліджуваних.

Нетривалий перегляд насильства по телебаченню чи за комп’ютером однозначно не спричиняє агресивної поведінки, проте може призводити до тимчасових агресивних афектів [17]. В той же час тривалий та частий перегляд такого контенту веде до формування ворожих рис особистості у глядача [18]. У дослідженнях учених зі США агресивні схильності, як і поведінка досліджуваних не вивчається виключно під упливом рецепції медіапродукції. Значний масив експериментальних статей розглядає медіанасильство як показане по телевізору або побачене на моніторі комп'ютера, в тому числі під час комп'ютерних ігор (це загалом вписується у визначення цього терміна, подане Л. Роуеллом-Х'юзменом). За свідченням К. Бартлетта, К. Андерсона та Е. Свінга, короткотривалі агресивний афект від насильницьких комп’ютерних ігор можуть тривати від 4 до 9 хвилин [17]. При цьому такі афективні стани при значному їх накопиченні можуть призводити до довготривалого ефекту десенситизації (до певної міри втрати чутливості) щодо агресії. В цьому контексті цікавим є експеримент Б. Бушмана та К. Андерсона [19] щодо порівняння впливу насильницьких відеофрагментів із фільмів на готовність допомагати іншим та швидкість відповідної реакції. Перевірялося це у польових умовах, коли після перегляду надворі досліджувані стали свідками наступної сцени. Жінка на милицях, асистент експериментатора, яка проходила повз, раптово втратила опору i, впавши на землю, не могла дотягнутися до милиць. При цьому вона не просила про допомогу. Виявилося, що група досліджуваних, які щойно переглянули відеофрагмент із насильством, довше зважувалися допомогти жінці, ніж ті, хто такі матеріали не переглядав.

Основою лабораторного різновиду таких досліджень є застосування методик психодіагностики, за допомогою яких можна оцінити рівень агресивності до і після перегляду певних видів медіаконтенту. До таких тестів належать: опитувальник агресії А. Басса Е.Даркі [20], тест «Агресивність у стосунках» А. Ассінгера [21] та тест на визначення внутрішньої агресивності С. Дайхоффа [22]. Об'єднує згадані методики психодіагностики можливість оцінити рівень агресивності людини. Проте кожен із тестів має свою специфіку. Опитувальник А. Басса - Е. Даркі дає можливість оцінити такі параметри агресивності,

\footnotetext{
2 Звісно, в передових університетах США та Західної Свропи вже зараз є переносні лабораторії для психофізіологічних вимірювань, які, проте, дають змогу лише збирати дані; подальша їх обробка відбувається лише фізично в приміщенні лабораторії, тому основна суть лабораторії як місця збору та обробки даних залишається актуальною.
} 
як «непряма агресія», «підозрілість», «негативізм», «образа» та інші. Тест А. Ассінгера фіксує схильність до агресивних почуттів досліджуваного щодо своїх колег, друзів та інших осіб. Тест С. Дайхоффа ідентифікує агресивність, яку досліджувані схильні не показувати назовні, а також спрямовану щодо самого себе.

3. Вивчення змін когнітивних особливостей досліджуваних, зокрема здатності сприймати та обробляти нову інформацію під упливом теленасильства. Такі зміни опосередковано можуть призводити до подальшого посилення або послаблення психоемоційної та поведінкової агресивності. Як у лабораторії, так «у полі» експеримент робиться за допомогою психодіагностичних методик, хоча може підкріплюватися застосуванням методик вимірювання психофізіологічних реакцій організму: частоти серцевих скорочень, шкірногальванічного рефлексу, електроенцефалограми, функціональної магнітно-резонансної томографії мозку тощо.

Як відбувається процес «когнітивного» експерименту? Досліджувані дивляться певні зразки телевізійного контенту, які містять або не містять насильства. Після перегляду вони виконують певні завдання для виявлення когнітивних здібностей. Серед методик вивчення впливу теленасильства на здатність засвоювати нову інформацію слід виокремити наступні: опитувальник переліку думок (thought-listing questionnaire) [2, 116: 23], тест на вільні асоціації з неагресивними словами або омонімами (одне зі значень останніх - більш агресивно конотоване) [2, 116: 24], а також завдання з формування слів із пропущеними літерами [2, 116: 25], в якому досліджуваний обирає слово агресивного / неагресивного емоційного навантаження. Цікаво, що в останньому дослідженні ті, хто перед тим слухали пісні з агресивними текстами, згодом обирали переважно слова такого ж значення.

Вітчизняними дослідниками $[26,23]$ для оцінок когнітивних можливостей досліджуваних був використаний тест на емоційне вигорання В. Бойка. Емоційне вигорання - це «вироблений особистістю механізм психологічного захисту у формі повного або часткового відключення емоцій у відповідь на певні подї чи процеси, щзо спричиняють дискомфорт» [27]. Одним із таких дискомфортних процесів є значний нині рівень інформаційного перенавантаження. Тож під упливом втрати чутливості до певного контенту може розвиватися втрата здатності сприймати нову інформацію.

4. Фіксація супутніх станів психіки, які можуть сприяти виникненню агресії. Такі стани оцінюються також за допомогою психодіагностичних опитувальників, які характеризують: ступінь особистісної та ситуативної тривожності (шкала особистісної та ситуативної тривожності Ч. Спілбергера - Ю. Ханіна [28]), оцінка настрою та самопочуття (опитувальник САН [29]). Ці методики не вказують на здатність сприймати й обробляти інформацію, а лише на емоційний стан до і після перегляду відібраного медіаконтенту.

Слід наголосити, що відмінність між третім та четвертим видами методик - у тому, що останній показує психоемоційний стан, третій же спрямовується на здатність індивіда сприймати й обробляти нову інформацію, в нашому випадку контент мас-медіа з умістом насильства.

У контексті згаданих напрямів досліджень короткотривалих ефектів медіавпливу доволі важливим їх елементом є вимірювання психофізіологічних реакцій. Якщо психодіагностика оцінює стани досліджуваних, то електрофізіологія їх вимірює. До таких методик належить фіксація таких параметрів: викликаних потенціалів головного мозку, функиіональної магніто-резонансної томографії мозку (ФМРТ), частоти сериевих скорочень, икірно-гальванічного рефлексу (ШГР), eye-tracking, а також реакиій міміки досліджуваних (система кодування виразів обличчя П. Екмана). Зупинімося на кожному з цих методів.

Фіксація викликаних потенціалів головного мозку (event-related potentials, ВП) вигідно вирізняється у застосуванні електрофізіології для пізнання медіаефектів. За останнє десятиліття було проведено чимало досліджень із використанням цього методу, який із більшою достовірністю дає змогу вимірювати і прогнозувати здатність досліджуваного 
сприймати і засвоювати нову інформацію [30; 31; 32]. Методика ВП дає змогу вивчити особливості уваги та сприйняття різними сенсорними системами нової інформації [33, 3$]$.

Функиіональна магніто-резонансна томографія мозку належить також до досить молодих методів в експериментах з вивчення ефектів медіанасильства. Метод оцінює активацію певних частин мозку під час впливу різних стимулів. Р. Вебер, Дж. Майкл Мангус та Р. Хаскі [34] подають основні засади використання цього методу для вивчення впливів контенту мас-медіа. Зокрема, вчені наголошують на тому, що головним мірилом для дослідника у доцільності застосування методу має бути зв'язок між розумовими процесами та ланцюжками нейронів у мозку [34, 7]. Якщо такий зв'язок можна буде простежити, то ФМРТ варта використання. В інших випадках така доцільність - під питанням. Тому щоб не виникало труднощів на етапі інтерпретації даних ФМРТ в таких експериментах, слід заздалегідь подбати про валідність та достовірність майбутніх висновків.

Метод шкірно-гальванічного рефлексу, або показників електричної провідності шкіри, також характерний для досліджень ефектів впливу медіанасильства. Проте зазвичай його не використовують сам, а тільки поряд з іншими вимірами психофізіологічних реакцій, як ось ФМРТ [30] чи частота серцевих скорочень [35]. Серед українських науковців ШГР вперше використав В. Різун [36; 37], який запропонував цей метод для оцінки процесу розуміння медійних текстів в контексті емоційного стану реципієнтів.

Eye-tracking не $\epsilon$ настільки популярним у працях із медіаефектів агресивного контенту, проте використовується переважно для досліджень ефективності різних видів реклами [28, 25-26]. Eye-tracking показує точку, на яку в певний момент перегляду був спрямований погляд досліджуваного, а також переміщення погляду монітором комп'ютера. Однак у дослідженнях впливу медіанасильства метод наразі не використовували. Тому свій потенціал в експериментах з ефектів відеонасильства цьому методу ще належить розкрити.

Методику розпізнавання емоційних реакцій обличчя П. Екмана - систему кодування виразів обличчя [38] - Ю. Гаврилець вперше використав для досліджень впливу теленасильства [3, 103-110]. Ї̈ї суть зводиться до наступного. Під час перегляду роликів за досліджуваними ведеться відеоспостереження і потім експериментатор розшифровує зміни виразів обличчя під час перегляду. Якщо шкірно-гальванічний рефлекс та частота серцевих скорочень дозволяють показати моменти найбільших підйомів і спадів емоційнофізіологічних реакцій (а тональність емоції - позитивну або негативну - неможливо встановити), то методика П. Екмана допомагає побачити, яку емоцію в певний момент під час перегляду ролика відчував досліджуваний.

\section{4. Висновки}

У масиві досліджень впливу телевізійного насильства на подальшу агресивну поведінку глядачів чи зростання агресивних схильностей у статті виокремлено чотири основні види методик: поведінкова агресія, оцінка психоемоційної агресивності, когнітивні особливості та загального психоемоційного та фізіологічного стану досліджуваних. Кожен із цих значних блоків досліджень має свою специфіку, для кожного з них є свої методи фіксації та інтерпретації даних. I кожен заслуговує застосування у вивченні медіаефектів.

Звісно, значна частина досліджень на межі соціальних комунікацій та психофізіології приречена натикатися на значний шквал критики 3 міркувань достовірності отриманих даних. Проте це не повинно зупиняти науковців від емпіричних пошуків у цій сфері. Досліднику варто вже на етапі формулювання гіпотези чітко розуміти, що саме досліджується. I якщо в точних науках об'єкт і предмет є однозначними за визначенням, то в медіаефектах навіть ті процеси та явища, які ледве піддаються підрахункові та вимірюванню, слід все ж таки формулювати кількісною мірою. Тому етап операціоналізації оцінних показників психологічних та соціальних процесів має за мету саме це. 
У статті поданий лише короткий типологічний огляд наявних методик, використовуваних західними науковцями. Зазначимо, що кожен конкретний експеримент вимагатиме своєї методики або їх поєднання, які найкраще зможуть розкрити суть досліджуваних ефектів мас-медіа та екстраполювати результати експериментів на значні генеральні сукупності.

Особливим сегментом у структурі методик ефектів теленасильства $є$ вимірювання психофізіологічних реакцій досліджуваних. На відміну від методик психодіагностики, вони не оцінюють, а вимірюють реакції, які для людини часто є неусвідомленими і не контролюються зусиллями волі. Важливо, що електрофізіологічні вимірювання надають дослідникові цінну інформацію про ті психоемоційні стани та їх силу, які та якою мірою відчувають під час перегляду досліджувані. Проте для більшої валідності даних експерименту слід поєднувати вимірювання, наприклад, ШГР або eye-tracking iз психодіагностичними анкетами.

За підсумками аналізу методик вивчення агресивності під упливом перегляду медіаконтенту можемо констатувати, що з огляду на слабкий рівень вивчення довготривалих медіаефектів, переважна більшість методик фіксує короткотривалі ефекти впливу і часто втрачає з поля зору довготривалі. В майбутніх статтях буде досліджено також особливості формування агресивних схильностей під упливом програм телебачення з плином часу.

\section{References}

1. Wilson, B. (2008), "Media and children's aggression, fear, and altruism", The Future of Children, vol. 18, no. 1, pp. 87-118.

2. Prot, S. \& Anderson, C.A. (2013), "Research methods, design, and statistics in media psychology", in Dill K. (Ed.), The Oxford Handbook of Media Psychology, Oxford University Press, New York, pp. 109-136.

3. Havrylets, Y.D. (2013), Short-Term Media Effects' Impact on Youth Student Groups (Based on the TV News), PhD diss. (soc. com.), Institute of Journalism, Taras Shevchenko National University of Kyiv, 265 p.

4. Szabo, A. \& Hopkinson, K. (2007), "Negative Psychological Effects of Watching the News in the Television: Relaxation or Another Intervention May Be Needed to Buffer Them!", International Journal of Behavioral Medicine, vol. 14, no. 2, pp. 57-62.

5. Millwood, A. (2003), "How Children Interpret Screen Violence", available at: http://downloads.bbc.co.uk/guidelines/editorialguidelines/research/violence-children.pdf, (accessed 01.09.2014).

6. Rizun, V.V. \& Skotnykova, T.V. (2008), Research Methods in Journalism Studies: a Textbook, Presa Ukrajiny, Kyiv, 144 p.

7. Huesmann, L.R. (2007), "The impact of electronic media violence: Scientific theory and research", Journal of Adolescent Health, no. 41, pp. 6-13.

8. Anderson, C. A. \& Bushman, B. J. (2002), "Human aggression", Annual Review of Psychology, no. 53, pp. 27-51.

9. Harris, R. J. (2004), A Cognitive Psychology of Mass Communication, L.Erlbaum Associates, $\mathrm{NJ}, 464 \mathrm{p}$.

10. Buss, A.H. (1961), The psychology of aggression, Wiley, New York, 307 p.

11. Milgram, S. (1963), "Behavioral Study of Obedience", Journal of Abnormal and Social Psychology, no. 67, pp. 371-378.

12. Donnerstein, E. \& Berkowitz, L. (1981), "Victim reactions in aggressive erotic films as a factor in violence against women", Journal of Personality and Social Psychology, no. 41, pp. $710-724$. 
13. Buss, A.H. \& Perry, M. (1992), “The Aggression Questionnaire”, Journal of Personality \& Social Psychology, no. 63, pp. 452-459.

14. Elliot, D.S., Huizinga, D. \& Ageton, S.S. (1985), Explaining delinquency and drug use, Sage, Beverly Hills, 176 p.

15. Anderson, C.A. \& Dill, K.E. (2000), "Video games and aggressive thoughts, feelings, and behavior in the laboratory and in life", Journal of Personality and Social Psychology, no. 78, pp. 772-790.

16. Charlton, T., Panting, C., Davie, R., Coles, D. \& Whitmarsh, L. (2000), “Children's playground behavior across five years of broadcast television: A naturalistic study in a remote community", Emotional and Behavioural Difficulities, no. 5 (4), pp. 4-12.

17. Bartlett, C.P., Anderson, C.A. \& Swing, E.L. (2009), "Video game effects confirmed, suspected and speculative: A review of the evidence", Simulation \& Gaming, no. 40, pp. 377403 .

18. Bartholow, B.D., Sestir, M.A., \& Davis, E. (2005), “Correlates and consequences of exposure to video game violence: Hostile personality, empathy, and aggressive behavior", Personality and Social Psychology Bulletin, no. 31, pp. 1573-1586.

19. Bushman, B.J. \& Anderson, C.A. (2009), "Comfortably numb: Desensitizing effects of violent media on helping others", Psychological Science, no. 20, pp. 273-277.

20. Literacy (2012), "Buss-Durkee Hostility Inventory Questionnaire", available at: http://www.literacy.com.ua/praktychna-psyhologija/289-psyhodiagnostyka/osobystisnitesty/915-opytuvalnyk-ahresii-basa-darki.html (accessed 26 September 2015).

21. Vsetesti (2011), "Test of aggressiveness in relationships of A. Assinger", available at http://vsetesti.ru/242/ (accessed 05 March 2015).

22. The Black Lady (2010), "Test of internal aggression of S. Dayhoff", available at: http://megan-i.blogspot.com/2010/06/blog-post_4520.html (accessed 05 March 2015).

23. Calvert, S.L. \& Tan, S. (1994), “Impact of virtual reality on young adults' pshysiological arousal and aggressive thoughts: Interaction versus observation", Journal of Applied Developmental Psychology, no. 15, pp. 125-139.

24. Bushman, B.J. (1998), "Priming effects of violent media on the accessibility of aggressive constructs in memory", Personality and Social Psychology Bulletin, no. 24, pp. 537-545.

25. Anderson, C.A., Carnagey, N.I. \& Eubanks, J. (2003), "Exposure to violent media: The effects of songs with violent lyrics on aggressive thoughts and feelings", Journal of Personality and Social Psychology, no. 84, pp. 960-971.

26. Havrylets, Y.D. (2014), "Traits of Psychological Diagnostics Methods in Social Studies and Communication", in Proceedings of the Ukrainian National Scientific Conference "Diagnostic Criteria and Methods of Measuring the Impact of Media”, Kyiv, 10 April 2014, Kyiv, pp. 2225.

27. Vodopiyanova, N.E. \& Starchenkova, E.S. (2008), Syndrome of Burnout: Diagnostics and Prevention, Piter Publishing Hourse, Saint-Petersburg, 336 p.

28. Psylist (2010), "Anxiety Inventory of C. Spielberger", available at: http://psylist.net/praktikum/istre.htm (accessed 26 September 2015).

29. Testoteka (2012), "Wellbeing, Activeness and Mood Inventory", available at: http://testoteka.narod.ru/lichn/1/28.html (accessed 26 September 2015).

30. Strenziok, M., Krueger, F., Deshpande, G., Lenroot, R.K., Van der Meer, E. \& Grafman J. (2011), "Fronto-parietal regulation of media violence exposure in adolescents: a multi-method study”, Social Cognitive and Affective Neuroscience, no. 6 (5), pp. 537-547.

31. Bartholow, B.D., Bushman, B.J. \& Sestir, M.A. (2006), "Chronic violent video game exposure and desensitization to violence: Behavioral and event-related brain potential data", Journal of Experimental Social Psychology, no. 42, pp. 532-539.

32. Carnagey, N.L., Anderson, C.A. \& Bartholow, B. D. (2007), "Media violence and social 
neuroscience. New questions and new opportunities", Current Directions in Psychological Science, no. 16 (4), pp. 178-182.

33. Dmytrotsa, O.M. (2005), Brain Event-Related Potentials in Conditions of Involuntary and Voluntary Attention in Adolescents, Abstract of the PhD diss. (biol. sci.), Ivan Franko Lviv National University, $22 \mathrm{p}$.

34. Weber, R., Michael Mangus, J. \& Huskey, R. (2015), "Brain Imaging in Communication Research: A Practical Guide to Understanding and Evaluating fMRI Studies", Communication Methods and Measures, no 9(1-2), pp. 5-29.

35. Carnagey, N.L., Anderson, C.A. \& Bushman, B.J. (2007), "The effect of video game violence on physiological desensitization to real-life violence", Journal of Experimental Social Psychology, no. 43, pp. 489-496.

36. Rizun, V.V. (1988), Definition of the Text Subject: Editorial Analysis Problem, Abstract of the PhD diss. (phil. sci.), Institute of Journalism, Taras Shevchenko National University of Kyiv, $22 \mathrm{p}$.

37. Rizun, V.V. (1997), "Using galvanic skin reflex as a method of studying of topic component structure", in Rizun V.V. (Ed.), Editing and Publishing: Experience, Problems and Future, Publishing Center "Kyiv University", Kyiv, pp. 159-163.

38. Ekman, P. (2010), Psychology of Emotions, Piter Publishing House, Saint-Petersburg, $334 \mathrm{p}$.

\section{Список джерел}

1. Wilson, B. (2008). Media and children's aggression, fear, and altruism. Future of Children, 18(1), 87-118.

2. Prot, S., \& Anderson, C. A. (2013). Research methods, design, and statistics in media psychology. Chapter in K. Dill (Ed.) The Oxford Handbook of Media Psychology $(109-136)$. New York: Oxford University Press.

3. Гаврилець Ю. Д. Короткотривалі медіаефекти в молодіжних студентських групах (на матеріалі теленовин): 27.00.01 / Київський національний ун-т ім. Тараса Шевченка / Гаврилець Юрій Дмитрович. - К., 2013. - 265 арк.

4. Szabo, A., Hopkinson, K. (2007), "Negative Psychological Effects of Watching the News in the Television: Relaxation or Another Intervention May Be Needed to Buffer Them!", International Journal of Behavioral Medicine, Vol. 14, No. 2, pp. 57-62.

5. Millwood, A. (2003), "How Children Interpret Screen Violence", available at: http://downloads.bbc.co.uk/guidelines/editorialguidelines/research/violence-children.pdf, (accessed 01.09.2014).

6. Різун В. В., Скотникова Т. В. Методи наукових досліджень у журналістикознавстві: навчальний посібник / Різун В. В., Скотникова Т. В. - 2-е вид., перероб. і доп. - К.: Преса України, 2008. - 144 с.

7. Huesmann, L. R. (2007). The impact of electronic media violence: Scientific theory and research. Journal of Adolescent Health, 41, S6-S13.

8. Anderson, C. A., \& Bushman, B. J. (2002). Human agression. Annual Review of Psychology, 53, 27-51.

9. Harris, R. J. (2004). A Cognitive Psychology of Mass Communication (4th ed.). Mahwah, NJ: Lawrence Erlbaum Associates.

10. Buss, A.H. (1961). The psychology of aggression, Wiley, New York, 307 p.

11. Milgram, S. (1963). "Behavioral Study of Obedience", Journal of Abnormal and Social Psychology, no. 67, pp. 371-378.

12. Donnerstein, E., \& Berkowitz, L. (1981). Victim reactions in aggressive erotic films as a factor in violence against women. Journal of Personality and Social Psychology, 41, 710-724. 
13. Buss, A. H., \& Perry, M. (1992). The Aggression Questionnaire. Journal of Personality \& Social Psychology, 63, 452-459.

14. Elliot, D. S., Huizinga, D., \& Ageton, S. S. (1985). Explaining delinquency and drug use. Beverly Hills, CA: Sage.

15. Anderson, C. A., \& Dill, K. E. (2000). Video games and aggressive thoughts, feelings, and behavior in the laboratory and in life. Journal of Personality and Social Psychology, 78, 772790.

16. Charlton, T., Panting, C., Davie, R., Coles, D., \& Whitmarsh, L. (2000). Children's playground behavior across five years of broadcast television : A naturalistic study in a remote community, Emotional and Behavioural Difficulities, no. 5 (4), pp. 4-12.

17. Bartlett, C. P., Anderson, C. A., \& Swing, E. L. (2009). Video game effects confirmed, suspected and speculative: A review of the evidence. Simulation \& Gaming, 40, 377-403.

18. Bartholow, B. D., Sestir, M. A., \& Davis, E. (2005). Correlates and consequences of exposure to video game violence: Hostile personality, empathy, and aggressive behavior. Personality and Social Psychology Bulletin, 31, 1573-1586.

19. Bushman, B. J., \& Anderson, C. A. (2009). Comfortably numb: Desensitizing effects of violent media on helping others. Psychological Science, 20, 273-277.

20. Опитувальник агресії Баса-Даркі [Електронний ресурс]. - Режим доступу: http://www.literacy.com.ua/praktychna-psyhologija/289-psyhodiagnostyka/osobystisnitesty/915-opytuvalnyk-ahresii-basa-darki.html. - Назва з екрану.

21. Оценка агрессивности в отношениях (А. Ассингер) [Электронный ресурс]. - Режим доступа : URL : http://vsetesti.ru/242. - Название с экрана.

22. Тест на определение внутренней агрессивности С. Дайхоффа [Электронный ресурс]. - Режим доступа: http://megan-i.blogspot.com/2010/06/blog-post_4520.html. - Название с экрана.

23. Calvert, S. L., \& Tan, S. (1994). Impact of virtual reality on young adults' pshysiological arousal and aggressive thoughts: Interaction versus observation. Journal of Applied Developmental Psychology, 15, 125-139.

24. Bushman, B. J. (1998). Priming effects of violent media on the accessibility of aggressive constructs in memory. Personality and Social Psychology Bulletin, 24, 537-545.

25. Anderson, C. A., Carnagey, N. I., \& Eubanks, J. (2003) Exposure to violent media: The effects of songs with violent lyrics on aggressive thoughts and feelings. Journal of Personality and Social Psychology, 84, 960-971.

26. Гаврилець Ю. Д. Особливості використання методів психодіагностики у соціальнокомунікаційних дослідженнях // Критерії діагностики та методики розрахунку впливу медіа : матеріали всеукраїнської науково-практичної конференції, 10 квітня 2014 р. - К.: Київський національний університет імені Тараса Шевченка, Інститут журналістики, 2014. - c. 22-25.

27. Водопьянова Н. Е., Старченкова Е. С. В62. Синдром выгорания: диагностика и профилактика. 2-е изд. - СПб.: Питер, 2008. - 336 с.

28. Тест «Исследование тревожности» (опросник Спилбергера) [Электронный ресурс]. - Режим доступа : URL : http://psylist.net/praktikum/istre.htm. - Название с экрана.

29. Опросник «САН» [Электронный ресурс]. - Режим доступа : URL : http://testoteka.narod.ru/lichn/1/28.html. - Название с экрана.

30. Strenziok, M., Krueger, F., Deshpande, G., Lenroot, R. K., Van der Meer, E., and Grafman J. (2011). Fronto-parietal regulation of media violence exposure in adolescents: a multimethod study. Social Cognitive and Affective Neuroscience, 6 (5), 537-547.

31. Bartholow, B. D., Bushman, B. J., \& Sestir, M. A. (2006). Chronic violent video game exposure and desensitization to violence: Behavioral and event-related brain potential data. Journal of Experimental Social Psychology, 42, 532-539. 
32. Carnagey, N. L., Anderson, C. A., \& Bartholow, B. D. (2007). Media violence and social neuroscience. New questions and new opportunities. Current Directions in Psychological Science, 16 (4), 178-182.

33. Дмитроца О. М. Викликані потенціали головного мозку в умовах мимовільної та довільної уваги у підлітків : автореф. дис. на здобуття наук. ступеня канд. біол. наук : спец. 03.00.13 «Фізіологія людини і тварин» / О. М. Дмитроца. - Львів, 2005. - 22 с.

34. Weber, R., Michael Mangus, J., \& Huskey, R. (2015). Brain Imaging in Communication Research: A Practical Guide to Understanding and Evaluating fMRI Studies, Communication Methods and Measures, 9: 1-2, 5-29.

35. Carnagey, N. L., Anderson, C. A., \& Bushman, B. J. (2007). The effect of video game violence on physiological desensitization to real-life violence. Journal of Experimental Social Psychology, 43 (2007), 489-496.

36. Ризун В. В. Определение темы текста: Проблема редакторского анализа / Ризун В. В.: Автореф. на соиск. уч. ст. канд. филол. наук. - Киев, 1988.- 22 с.

37. Різун В. В. Використання шкірно-гальванічного рефлексу як методу вивчення компонентної будови теми / Різун В. В. // Редакційно-видавнича справа: досвід, проблеми, майбутнє / За ред. В. В.Різуна. - К.: РВЦ "Київ. ун-т", 1997. - С. 159-163.

38. Экман П. Психология эмоций. Я знаю, что ты чувствуешь / П. Экман [пер. с англ.] - СПб.: Питер, 2010. - 334 с.: ил. 